\title{
Management of Early Congenital Syphilis in a Newborn Case with Maculopapular Rash
}

\section{Makülopapüler Döküntüsü Olan Erken Konjenital Sifilizli Olguda Tedavi Yönetimi}

\author{
Özgün Uygur1, Burçe Emine Yaşar1, Zümrüt Şahbudak Bal2, Özge Altun Köroğlu1, \\ Mehmet Yalaz1, Mete Akisü1, Fadıl Vardar2, Nilgün Kültürsay1 \\ ${ }^{1}$ Ege University Faculty of Medicine, Department of Pediatrics, Division of Neonatology, Izmir, Turkey \\ 2Ege University Faculty of Medicine, Department of Pediatrics, Division of Pediatric Infectious Diseases, Izmir, Turkey
}

\begin{abstract}
Congenital syphilis is preventable with proper antenatal follow-up and treatment of the pregnant woman infected with Treponema pallidum, and the rapid evaluation and early treatment of the newborns. Here we report a newborn with early congenital syphilis presenting with maculopapular rash and positive treponemal test born to an inadequately treated syphilitic mother.

Keywords: Syphilis, congenital, maculopapular rash, newborn
\end{abstract}

ÖZ

Konjenital sifiliz, Treponema pallidum ile enfekte olan annelerin prenatal dönemde düzenli izlem ve etkin tedavilerinin sağlanması, doğum sonrası bebeklerin hızla değerlendirilip erken tedavi edilmeleriyle önlenebilir. Burada annesi sifiliz tanısıyla yetersiz tedavi almış, makülopapüler döküntülerle başvuran maternal treponemal testi pozitif saptanarak erken konjenital sifiliz tanısıyla başarılya tedavi edilen yenidoğan hasta sunulmaktadır.

Anahtar Kelimeler: Sifiliz, konjenital, makülopapüler döküntü, yenidoğan

\section{Introduction}

Treponema pallidum, which causes syphilis, is a microaerophilic, mobile, Gram-negative spirochete. It is usually transmitted by sexual contact $(1,2)$. Congenital syphilis is a clinical state caused by the transmission of the spirochetes from the infected mother to the baby. The baby is infected mostly transplacentally or by contact with active lesions during labor. Placental transmission incidence is 70-100\% for primary syphilis, 40\% for early latent syphilis, and $10 \%$ for late latent syphilis (3).
Congenital acquired infection may lead to abortion, stillbirth, prematurity, low birth weight, and a severe clinical manifestation in the neonatal period $(1,4)$. However, the early treatment at the onset of syphilis may prevent the development of severe syphilis and late syphilis symptoms (5).

In this report, a case born to a mother with syphilis, and diagnosed via maculopapular rash on the second day of life is described in order to emphasize the importance of early treatment in congenital syphilis. Written informed consent was obtained from the family for the publication of this case report. 


\section{Case Report}

A 3530 gram male infant who was born to a 31-year-old mother with syphilis at 38 weeks' gestation by C-section was hospitalized at our neonatal care unit for further examination and treatment. The Venereal Diseases Research Laboratory (VDRL) test and the T. pallidum hemagglutination test (TPHA) were found to be $1 / 320$ positive on the first day of life at the center where the baby was born. It was learned that the mother was being followed up from 2008 onwards due to the diagnosis of syphilis, and she had been treated with a total of 8 injections of benzyl penicillin during the pregnancy period (1.2 million units in the 22nd week, 2.4 million units in week 33, and 2.4 million units in the 34th week of gestational age). Serological tests of the mother are shown in Table I.

The baby was born to nonconsanguineous parents both diagnosed with syphilis, with assisted reproduction [in vitro fertilization and embryo transfer (IVF-ET)] after three years of infertility treatment. It was reported by the mother that regular pregnancy follow-ups were performed at the same center, no problems were detected during the pregnancy period and the doppler ultrasonography and detailed ultrasonographic examinations were interpreted as normal.

The first physical examination at the 48th hour of life showed his weight as 3270 grams (75-90th percentile), height 52 centimeters (75th percentile), and head circumference as $34.9 \mathrm{~cm}$ (75-90th percentile). There was a weight loss of $7 \%$

Table I. Serologic tests of the mother during the whole diagnostic period

\begin{tabular}{|l|l|l|l|}
\hline Date & VDRL & TPHA & Gestational age \\
\hline $17.11 .2008^{*}$ & $1 / 8$ & $1 / 1280$ & \\
\hline $22.02 .2009^{*}$ & $1 / 8$ & $1 / 640$ & \\
\hline $10.08 .2009^{*}$ & $1 / 4$ & $1 / 160$ & \\
\hline $07.04 .2010^{*}$ & $1 / 2$ & $1 / 160$ & \\
\hline $22.11 .2010^{*}$ & $1 / 8$ & $1 / 640$ & \\
\hline $23.01 .2012^{*}$ & $1 / 1$ & $1 / 160$ & \\
\hline $\begin{array}{l}\text { 18.07.2012* } \\
\text { 04.02.2013* }\end{array}$ & $1 / 1$ & $1 / 320$ & \\
\hline 28.08.2013* & Negative & $1 / 160$ & \\
\hline 08.05.2014 & Negative & $1 / 160$ & \\
\hline 21.08.2014 & Negative & $1 / 320$ & $17^{\text {th GA }}$ \\
\hline 23.09.2014 & Negative & $1 / 320$ & $32^{\text {nd } G A}$ \\
\hline $\begin{array}{l}\text { *These tests belong to the period before pregnancy } \\
\text { VDRL: Venereal Diseases Research Laboratory, TPHA: } \\
\text { hemagglutination test, GA: Gestational age }\end{array}$ & Negative & $1 / 320$ & $36^{\text {th GA }}$ \\
\hline
\end{tabular}

by birth. The vital signs were within normal limits. He had jaundice only in his face and also widespread hyperemic macular rash in the whole body. The front fontanele was $1 \times 1 \mathrm{~cm}$ and the back fontanele was $0.5 \times 0.5 \mathrm{~cm}$. The cardiovascular and respiratory system examinations gave normal results. No organomegaly was detected. Newborn reflexes and tonus were evaluated as normal. Biochemical tests revealed no pathology other than hyperbilirubinemia within the physiological limits. Coagulation cascade profile was normal and infection markers were negative.

No pathology was found in whole body bone survey in terms of bone pathologies. Ophthalmologic evaluation for chorioretinitis was interpreted as normal. Auditory brainstem response audiometry test was performed and no hearing loss was detected. Lumbar puncture was planned for neurosyphilis, but could not be performed because his parents did not give consent to the procedure. Transfontanel and abdominal ultrasonography was normal. Patent foramen ovale was detected in the echocardiography. The VDRL titration at birth was not known for the mother and the baby had had a positive VDRL test at another center with an unknown titre. According to the treatment algorithms (Figure 1) for the cause of nonspecific macular rash on the occasion, treatment was started with crystallized penicillin as $50.000 \mathrm{U} /$ $\mathrm{kg} /$ dose in the first five days, two doses per day $(5,6)$. After the 7th day of life, the treatment was completed at 10 days with three doses per day.

The VDRL/rapid plasma reagin (RPR) test sent in the $48^{\text {th }}$ hour of treatment was negative. Anti-T. pallidum

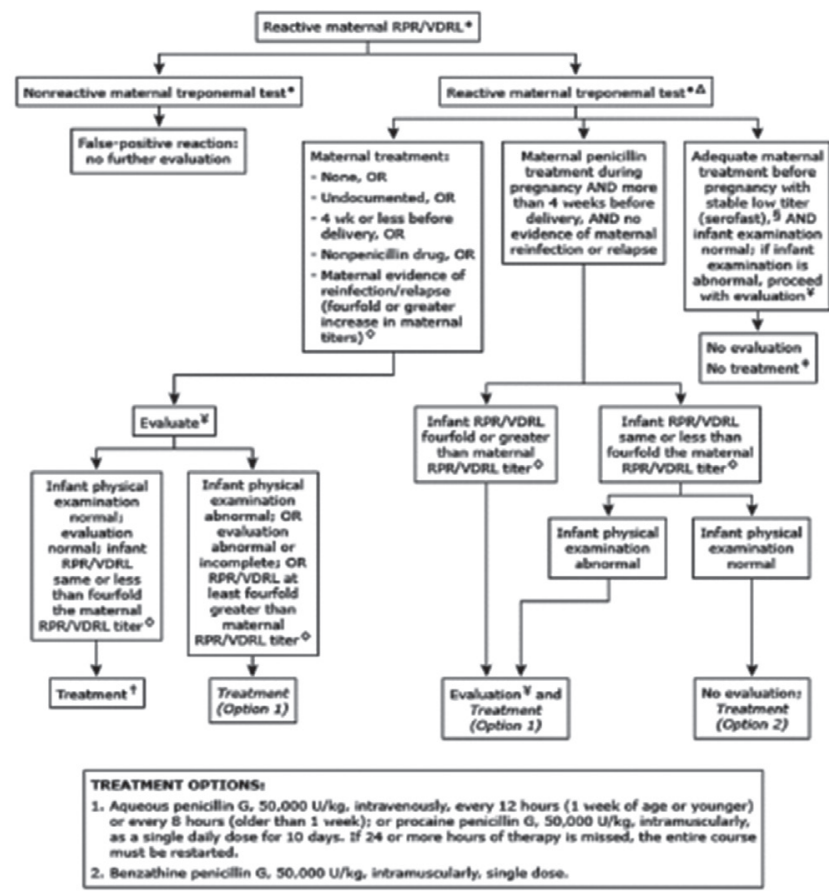

Figure 1. Congenital syphilis treatment algorithm published by the American Academy of Pediatrics, 2012 (7)

RPR: Rapid plasma reagin, VDRL: Venereal Diseases Research Laboratory 
immunoglobulin (lg) $\mathrm{G}+\operatorname{lgM}(23.83 \mathrm{IU} / \mathrm{mL})$ was detected positive. The results were evaluated as treatment efficacy. At the end of the treatment VDRL test control was planned. During the follow-up, a rapid recovery was observed in the rash and he was discharged from the hospital. The baby is now 3 months old and has had no complaints during this period. VDRL/RPR tests were negative after treatment and at the third month of life, also T. pallidum lgG + lgM levels of the patient were decreased at the third month control (22.42$13.48 \mathrm{IU} / \mathrm{mL})$.

\section{Discussion}

Although the treatment of congenital syphilis is simple and effective, it is still an important health problem today. According to World Health Organization 2008 data, approximately 1.9 million syphilis-infected women get pregnant each year. Half of these pregnancies have negative consequences including syphilis-related abortion, stillbirth and many severe clinical symptoms (4).

In congenital syphilis, multiple common severe organ involvements or only laboratory findings may be observed due to antenatal hematogenous spread. Congenital syphilis is divided into two catagories according to the time of appearance of the clinical findings. Early congenital syphilis is defined when the clinical findings are observed in the first two years of life. The group that is clinically symptomatic until 20 years of age after two years of life is considered late congenital syphilis.

In early congenital syphilis, the most common finding in infected infants is hepatomegaly and is observed in almost all infected infants (7). Jaundice and elevated transaminase enzymes can also be detected due to hepatic involvement $(2,8)$. Skin rashes observed in $68 \%$ of congenital syphilis newborns are another common finding. Bullous and nonspecific maculopapular rashes involving the palms and soles of the feet are also frequently seen. The only pathological finding in our case was maculopapular rash. Syphilitic rhinitis, which is the earliest finding that can be seen in the first week of life, is often serious, it can be bloody and purulent, and is very infectious. Also bone pathologies due to syphilis involve more than one bone, usually bilateral and symmetric. Osteochondritis, which is observed the most, may cause pain and limit the movements of the baby. Therefore, this clinical situation is called "Parrot's pseudoparalysis".

Neurosyphilis is asymptomatic in $40 \%$ of the patients and has two clinical presentations. The symptoms of acute syphilitic leptomeningitis are observed usually within the first year, especially in the first 3-6 months. The clinical findings are similar to those of bacterial meningitis with symptoms including vomiting, nourishment disorders, fontanel bulging and rapid increase around the head. However, there is a resemblance between the findings of cerebrovascular fluid to aseptic meningitis, and there is mononuclear cell dominance. This clinical state responds quickly to antibiotics. Chronic meningovascular syphilis, symptomatic at the end of the first year of life, is characterized by hydrocephalus, cranial nerve paralysis, growth retardation, optic atrophy and seizures $(2,7)$.

The most common laboratory findings in congenital syphilis are anemia (58\%), thrombocytopenia and leukopenia/ leukocytosis (72\%) (8). Nonimmun hydrops fetalis may occur rarely due to anemia.

Late-stage congenital syphilis symptoms are present in approximately $40 \%$ of the patients who do not receive early treatment, and these findings are often irreversible. Saddle nose, saber shin tibia, short maxilla, frontal protrusion can occur due to bone destruction. Dental anomalies can develop as a result of syphilitic vasculitis. The most common dental changes are half-moon shaped notches on the free edges of the upper cutter teeth. These lesions called Hutchinson's teeth are the most common specific dental lesions (8). Because they are seen in the fixed teeth coming after the milk teeth, they are accepted as persistent symptoms (9). For this reason, regular teeth control is recommended for children after six years of age. One of the most important findings of late-stage syphilis is the $8^{\text {th }}$ cranial nerve paralysis, which usually manifests itself with hearing loss at the age of 8-10 $(2,7)$. The coexistence of Hutchinson's teeth, interstitial keratitis, and sensorineural hearing loss are defined as the "Hutchinson triad".

Dark field microscopy, direct fluorescent antibody testing, and DNA-polymerase chain reaction testing can be performed for the diagnosis of syphilis but all these methods are difficult to apply. Therefore, serological tests are used today because they are often cheaper and faster. While non-treponemal tests (NTTs), VDRL test and RPR tests are used for screening, follow-up and treatment, treponemal tests are used to verify the diagnosis (7). Treponemal tests can be classified as T. pallidum immobilization (TPI) test, TPHA, fluorescent treponemal antibody test, and microhemagglutination assay- . pallidum test. In our case, VDRL from NTTs and T. pallidum lgG + M from treponemal tests were positive, and both of the tests showed a decrease with the treatment.

After being successfully used in the treatment of three syphilitic patients, penicillin became the most effective treatment worldwide. In our case, penicillin treatment was applied for ten days in accordance with this algorithm $(5,6)$. VDRL/RPR tests were negative after treatment and at the third month of life; also T. pallidum lgG + IgM levels of the patient were decreased at the third month control.

The treatment decision in congenital syphilis cases is given according to clinical findings, maternal treatment duration, and non-treponemal test titres of mother and baby at birth in accordance with the treatment modalities of the American Academy of Pediatrics (2012) and the US Centers for Disease Control and Prevention (CDC) (2010) $(5,6)$. It is recommended that NTT titres should be monitored with 3-month-intervals after the treatment of seroreactive newborns. Fourfold reduction is expected by the sixth month in the titres of the patients receiving adequate treatment. If 
there is no decrease, or an increase is detected in the titres, the cases should be re-evaluated in terms of treatment resistance, efficacy and neurosyphilis. Positivity of the treponemal tests may continue until the $15^{\text {th }}$ month of life. Ongoing treponemal test positivity at the $18^{\text {th }}$ month of life requires re-evaluation (7). According to the recommendations of the CDC, three doses of benzyl penicillin treatment are required with a weekly interval to give a total of 7.2 million units during pregnancy if the latent period phase of the pregnant woman is unclear. In our case, maternal treatment with a total of six million units of benzyl penicillin during pregnancy was considered inadequate $(1,5,6)$, and therefore the baby was treated.

The main drawback to preventing congenital syphilis is the inadequate diagnosis and treatment processes of antenatal regular follow-ups of the pregnant women. NTT examination and treatment according to the titre is recommended in the first control, at the third trimester and at birth. However, even in developed countries, only $68 \%$ of the pregnant women have regular follow-ups, and half of them have their first control at the end of the first trimester (9).

In conclusion, with the regular follow-up of syphilis during pregnancy, the effective treatment of the pregnant women, and with the early treatment of infants after a rapid evaluation, the complications of congenital syphilis can be prevented.

\section{Ethics}

Informed Consent: Written informed consent was obtained from the family for the publication of this case report.

Peer-review: Externally peer-reviewed.

\section{Authorship Contributions}

Surgical and Medical Practices: Ö.U., Z.Ş.B., Ö.A.K., M.Y., M.A., F.V., N.K., Concept: Ö.A.K., N.K., Design: Ö.A.K., N.K., Data Collection or Processing: Ö.U., B.E.Y., Analysis or
Interpretation: Ö.A.K., N.K., Literature Search: B.E.Y., Writing: Ö.U.

Conflict of Interest: No conflict of interest was declared by the authors.

Financial Disclosure: The authors declared that this study received no financial support.

\section{References}

1. Centers for Disease Control and Prevention. STD Surveillance case definitions. http://www.cdc.gov/std/stats/ CaseDefinitions-2014.pdf (Accessed on March 21, 2014).

2. Woods CR. Syphilis in children: congenital and acquired. Semin Pediatr Infect Dis 2005;16:245-57.

3. Can E, Bülbül A, Cömert $S$, Bolat $F$, Okan F, Nuhoğlu A. Cilt Bulguları ile Tanı Konulan Doğumsal Sifiliz Olgusu. Çocuk Enf Dergisi 2009;3:31-4.

4. World Health Statistics 2011. Geneva, World Health Organization, 2011 http://www.who.int/whosis/whostat/ EN_WHS2011_Full.pdf (accessed 15 October 2011).

5. Workowski KA, Berman S; Centers for Disease Control and Prevention (CDC). Sexually transmitted diseases treatment guidelines, 2010. MMWR Recomm Rep 2010;59:1-110.

6. American Academy of Pediatrics. Syphilis. In: Red Book: 2012 Report of the Committee on Infectious Diseases, 29th ed, Pickering LK (Ed), American Academy of Pediatrics, Elk Grove Village, IL 2012. p. 690

7. De Santis M, De Luca C, Mappa I, et al. Syphilis Infection during pregnancy: fetal risks and clinical management. Infect Dis Obstet Gynecol 2012;2012:430585.

8. Jensen HB. Congenital syphilis. Semin Pediatr Infect Dis 1999;10:183-94.

9. Chowdhary N, Rani BK, Mukunda KS, Kiran NK. Early detection of congenital syphilis. J Indian Soc Pedod Prev Dent 2014;32:333-7. 